\title{
ROUTLEDGE HANDBOOK OF DISABILITY STUDIES
}

\author{
Second edition
}

Edited by Nick Watson and Simo Vehmas

First published 2020

ISBN: 978-1-138-36530-8 (hbk)

ISBN: 978-0-429-43081-7 (ebk)

\author{
Chapter 6 \\ Disability and Human Rights \\ Lucy Series
}

(CC BY-NC-ND 4.0)

(2) $\begin{aligned} & \text { Routledge } \\ & \text { Taylor \& Francis Group }\end{aligned}$ 



\title{
6 \\ DISABILITY AND HUMAN RIGHTS
}

\author{
Lucy Series
}

The United Nations (UN) Convention on the Rights of Persons with Disabilities (CRPD) was the first human rights treaty to be developed by disabled people, for disabled people. Adopted by the UN in 2006, the Convention embodies and enshrines key tenets of contemporary disability scholarship and activism - from 'nothing about us without us' to a social understanding of disability. The CRPD is fertile terrain for disability scholarship - empirical, theoretical and critical. This chapter provides an overview of the history of human rights, the development of the disability Convention, and its main features and achievements. The chapter introduces some key areas of discussion and debate emerging in the literature on disability and human rights.

\section{Human rights prior to the disability Convention}

Human rights are legal and moral norms that aim to both define and protect fundamental freedoms and entitlements for all humans. An appreciation of contemporary disability human rights, as embodied by the CRPD, requires an understanding of what came before.

\section{Rights, revolutions and the Enlightenment}

There are examples of charters or bills of rights dating back to the ancient world, but our modern understanding of rights (in the West, at least) is closely linked to Renaissance humanism and the Enlightenment (Nickel 2017). In the seventeenth and eighteenth centuries rights became the ideology of revolutionaries, enshrined in the English Bill of Rights (1689), the French Declaration of the Rights of Man and the Citizen (1789), and the Bill of Rights in the United States Constitution (1791). Klug (2000: 71-72) describes this 'libertarian wave' of rights as primarily concerned with 'liberty from state tyranny and religious persecution', constructing the state as 'always and forever a threat to individual freedom'.

This body of rights rests on a fictive liberal subject - law's 'classic contractor' who is 'morally and legally accountable for his actions because his actions are guided by reason', standing 'alone, independently of all other individuals', and capable of enforcing his own rights (Naffine 2003: 66). It is underpinned by the often inherently ablest liberal philosophies of John Locke, Immanuel Kant, Jean-Jacques Rousseau, Thomas Paine and John Stuart Mill. 
Critiquing or adapting liberal theory for people with cognitive impairments is now a major intellectual project for contemporary political theory and moral philosophy (e.g. Kittay and Carlson 2010; Clifford Simplican 2015; Nussbaum 2009; Vorhaus 2005).

\section{Human rights: The post-war settlement}

'Human rights' as we know them today emerged from the aftermath of the Second World War. They are embodied by the Universal Declaration of Human Rights (UDHR), adopted by the UN in 1948, and the succession of binding international Conventions that followed. The norms underpinning these instruments transcended and expanded upon earlier liberal theories of rights.

\section{Human rights as an international concern}

Whereas previously rights were legislated at the national level, contemporary human rights are both guaranteed by, and play a role in guaranteeing, a global political order. During the twentieth century the abuse of minorities came to be regarded as a threat to peace and stability (Bates in Moeckli et al. 2014). The preamble to the UDHR describes the 'equal and inalienable rights of all members of the human family' as 'the foundation of freedom, justice and peace in the world'. Within this 'public morality of world politics', each person 'is a subject of global concern' (Beitz 2009: 1).

The use of international legal and diplomatic machinery to enforce and monitor human rights marks the end of a 'virtually unquestioned supremacy of the doctrine of national sovereignty' (Klug 2000: 96). Critics of human rights argue that this form of 'global governance' threatens national liberal democracy (Holbrook and Allan 2017) and privileges "new forms of “ethical” elite paternalism' (Chandler 2001: 72). Critical legal academics note concerns about Western moral imperialism (Donnelly 1984), others question whether rights really are 'a barrier against domination and oppression, or the ideological gloss of an emerging empire?' (Douzinas 2007: 1). Few proponents of human rights engage with these critiques, often viewing them more as a 'matter of faith rather than reason' (Besson in Moeckli et al. 2014: 35). Yet they do have an impact on the willingness of states to sign and ratify binding Conventions like the CRPD, and on the domestic reception of criticisms from the international human rights community.

\section{Universalism: dignity and equality}

The rights-based constitutions of the Enlightenment coexisted alongside the denial of rights to large swathes of the population - notably women, children, slaves, religious and ethnic minorities, and colonised peoples. In contrast, a central tenet of contemporary human rights is universalism. The twin foundations of this universalism are respect for the 'inherent dignity' of all humans, and equality. Article 1 of the UDHR states that 'all human beings are born free and equal in dignity and rights'.

The concept of 'human dignity' notoriously evades straightforward definition (Feldman 1999). Klug (2000: 101) suggests that for the drafters of the UDHR, surveying the 'inhumanity' that had been practised by individuals towards their fellow human beings, 'freedom was an insufficient basis on which to build the peaceful and tolerant world they sought to achieve'. It has been suggested that dignity, unlike liberty, involves recognising and responding to human vulnerability (Neal 2012; Turner 2006). 
Dignity, rather than liberty, as the foundation of human rights, fundamentally transforms the relationship between the individual and the state. The state must do more than simply refrain from interference and oppression, and must take proactive steps as the guarantor of human rights (Klug 2000). A focus on civil and political rights alone ignores the material constraints on freedom posed by economic inequality (Marx 1844). But 'dignity' provided a conceptual vehicle for introducing the 'economic, social and cultural rights indispensable for his dignity' (Article 22 of the UDHR), including the right to 'work' (Article 23 of the UDHR), 'rest and leisure' (Article 24 of the UDHR), 'to a standard of living adequate for the health and wellbeing of himself and of his family' (Article 25 of the UDHR), to education (Article 26 of the UDHR) and to freely participate 'in the cultural life of the community' (Article 27 of the UDHR).

Although the UN General Assembly recognised in 1950 that 'the enjoyment of civil and political freedoms and of economic, social and cultural rights are interconnected and interdependent', they are afforded different status and protection under international law. Economic, social and cultural rights are subject to the doctrine of 'progressive materialisation' to the maximum of a state's available resources. Civil and political rights - such as rights to liberty, to vote, and equal recognition before the law - must be realised immediately (van Boven in Moeckli et al. 2014). The distinction is also reflected in separate Covenants at the UN level, including the 1966 International Covenant on Civil and Political Rights and the 1966 International Covenant on Economic, Social and Cultural Rights. The 1950 European Convention on Human Rights (ECHR) chiefly enshrines civil and political rights.

\section{The seeds of a disability human rights settlement}

Several characteristics of the post-war human rights settlement were promising from a disability perspective: states must do more to protect rights than merely refrain from intervention, a concern with social, economic and cultural matters as well as civil and political rights, and the universalism and emphasis on equality inherent in human rights discourse requires reinforcement. Yet by the turn of the century, disabled people and disability organisations widely perceived that these instruments were failing to deliver this promise. There were mounting calls for a binding international Convention to specifically address the rights of disabled people. Yet if previous human rights instruments were universal in scope, why should such a Convention be needed?

\section{Towards a binding Convention on the Rights of Persons with Disabilities}

Despite the proclaimed universalism of human rights instruments such as the UDHR, the ICCPR and the ICESCR, several scholars have argued, convincingly, that disabled people were invisible in the international human rights community (Dhanda 2006-2007; Kanter 2015; Kayess and French 2008; Quinn 2009). The example that is frequently given is the text of Article 2 of the UDHR, replicated in Article 19 of the ICCPR and in Article 14 of the ECHR. This non-discrimination provision was introduced to protect minorities perceived as being particularly at risk of discriminatory treatment and human rights abuses, but there is no mention of disabled people:

Everyone is entitled to all the rights and freedoms set forth in this Declaration, without distinction of any kind, such as race, colour, sex, language, religion, political or other opinion, national or social origin, property, birth or other status. 


\section{Disability and human rights}

As Kanter (2015: 26) notes, although millions of disabled people were killed and maimed by the Nazis, they 'were simply not seen as worthy of human rights or legal protection' by the drafters of these Conventions. Even worse than merely invisible, the framers of the ECHR decided against an explicit prohibition on forced sterilisation because many European states still operated eugenic policies of involuntary sterilisation of disabled people (European Commission of Human Rights 1955).

From the 1970s onwards there was slow recognition that disabled people were rights bearers under international law. The UN adopted non-binding 'declarations' on the rights of 'mentally retarded' (1971) and 'disabled persons' (1975). These declarations employed medical model definitions of disability and recognised equal rights only 'to the maximum degree of feasibility' (United Nations 1971).

The year 1981 was proclaimed by the UN as the 'International Year of Disabled Persons' and special rapporteurs were appointed to prepare global reports on the conditions of disabled people (Daes 1986; Despouy 1991). Despouy reported that:

[Persons with disabilities] frequently live in deplorable conditions, owing to the presence of physical and social barriers which prevent their integration and full participation in the community. As a result, millions of children and adults throughout the world are segregated and deprived of virtually all their rights, and lead a wretched, marginal life.

(Ibid.: para. 3)

In 1991 the UN adopted the 'MI Principles' on 'the protection of persons with mental illness and the improvement of mental health care'. Only one disability organisation (Disabled Peoples' International) had observer status on the working group; the other observers were medical, legal or religious organisations (Steel 1991). Disability organisations acknowledged the advocacy potential of the MI Principles, but noted their inherent paternalism (Rosenthal and Rubenstein 1993).

The second half of the twentieth century witnessed a global backlash against the institutionalisation of disabled people - in rhetoric at least, if not always in reality. Politically engaged organisations led by disabled people developed distinctive understandings of rights and equality, based around social and minority rights understandings of disability. They campaigned for equality, inclusion and rights to independent living. Key milestones at the national level - such as the Americans with Disabilities Act 1990 - preceded equivalent rights in international law. The Organization of American States adopted the first international prohibition on disability discrimination in 1999, in the shape of the Inter-American Convention on the Elimination of All Forms of Discrimination against Persons with Disabilities. In contrast, the European Court of Human Rights did not recognise disability discrimination until 2009 (Glor v. Switzerland).

The UN began to develop binding Conventions addressing the concerns of specific communities, including women (UN 1979), children (UN 1989), and migrant workers (UN 1990). It introduced innovative monitoring and enforcement mechanisms to prevent torture and inhuman and degrading treatment in places of detention (UN 2006). Despouy (1991: 72) noted that disabled people were 'at a legal disadvantage in relation to other vulnerable groups such as refugees, women, [and] migrant workers'. Disability advocacy organisations began to designate policy officers to follow human rights developments (Quinn and Degener 2002). There were calls for a disability Convention (Darrow 1996).

At the turn of the millenium, national and international disability organisations met in Beijing, People's Republic of China, 'to develop a new century strategy for the full 
participation and equality of people with disabilities'. Noting the failure of earlier human rights instruments to significantly improve the lives of people with disabilities, these organisations committed 'to strive for a legally binding international convention on the rights of all people with disabilities to full participation and equality in society' (Disabled Peoples' International et al. 2000).

In 2001 a UN resolution sponsored by Mexico resulted in the establishment of an ad hoc committee to consider proposals for a Convention. The 'Ad Hoc Committee on a Comprehensive and Integral International Convention on the Protection and Promotion of the Rights and Dignity of Persons with Disabilities' met eight times to discuss and negotiate the text of the Convention (UN Enable).

The Convention was formally adopted by the UN on 13 December 2006 and entered into force on 3 May 2008. The CRPD human rights treaty was the fastest negotiated treaty at the UN, and the second fastest to be ratified, with the most signatures on its opening day (Stein and Lord 2009). It was the first UN human rights treaty to be negotiated and signed by the European Union (EU), as a 'state' in its own right. But the CRPD's most significant legacies are the means by which it was negotiated and the 'paradigm shift' it promises in approaches to disability and human rights.

\section{The UN Convention on the Rights of Persons with Disabilities}

\section{A 'paradigm shift' in human rights}

The UN Convention on the Rights of Persons with Disabilities has been widely hailed by scholars and activists as a 'paradigm shift' in approaches to disability and human rights (e.g. Kanter 2006-2007; Lawson 2006-2007; McKay 2006-2007; Kayess and French 2006-7). Kuhn ([1962] 2012) developed the concept of a 'paradigm shift' in his landmark book The Structure of Scientific Revolutions. 'Normal science' proceeds within a particular paradigm, based on a specific epistemology and ontological understandings that both define the nature of the problems and prescribe the approach to solving them. Anomalies begin to accumulate, which initially are disregarded but which eventually result in a crisis for the paradigm itself. Ultimately, the crisis is resolved by the introduction of a new paradigm, which can make sense of these anomalies, but only through an 'epistemological break' with the old paradigm.

The language of a 'paradigm shift' has been used to convey a sense that the existing paradigm of human rights has been ineffective for disabled people, and that what is required is not merely a tinkering with existing human rights instruments but a fundamental shift in their underlying epistemologies and norms. It signals that the CRPD will be perceived by many as disruptive, and will involve an intellectual 'battle' for acceptance, necessitating the 'reconstruction of the field from new fundamentals' and changing 'some of the field's most elementary theoretical generalizations as well as many of its paradigm methods and applications' (Kuhn [1962] 2012: 84).

The following description by Thomas Hammarberg, a former Council of Europe High Commissioner for Human Rights who initiated and oversaw many CRPD-inspired initiatives, captures the flavour of this paradigm shift:

The last decades have been marked by a shift in thinking. From viewing disability as a personal problem that needs to be cured (the medical model), we have come to see the source of the problem: the society's attitude towards persons with disabilities. This means that we have to act collectively as a society in order to remove the 
barriers that hinder persons with disabilities from living among us and contributing to our society, and to fight against their isolation in institutions or in the backrooms of family homes. Finally, there has been a shift from welfare policies and charity as the only tools for dealing with disability, to an approach based on human rights and equality.

(2011: 639)

It has in its sights many of the normative and epistemological underpinnings of earlier iterations of disability human rights - rejecting, for example, the medical model understanding of disability that runs through the MI Principles and the UN Declarations from the 1970s. According to Quinn and Arstein-Kerslake, this shift involves a fundamental reconceptualisation of what it means to be human, a rejection of the myth of the "masterless man freely choosing his/ her own conception of the good and wandering purposively in an anomic no-man's land', and in its place 'a frank acknowledgement of shared personhood and of the myriad or supports formal and informal - that we all rely on to help us forge our own pathways and the critical importance of participation and the ethic of belonging that it instils' (2012: 37). From this perspective, the CRPD is not merely a disability Convention, but is 'the latest iteration of a cosmopolitan theory of justice that happens to be grounded on disability' (ibid.: 38).

Implicit in the CRPD is an understanding by those who framed it that how we understand disability transforms how we respond to it, that questions of epistemology and ontology ultimately influence the material conditions and relationships of power that shape lives. The CRPD's epistemological and normative break with what came before is signalled in both the considerable length of its Preamble - whose function is to assist in treaty interpretation and to give 'traction to norm development and evolution' (Lord in Bantekas et al. 2018: 7) - and provisions requiring states parties to engage in 'awareness raising'.

Article 8 of the CRPD obliges states parties to the Convention to adopt immediate, effective and appropriate measures to raise awareness throughout society - 'including at the family level' - regarding persons with disabilities, to combat stereotypes, 'promote awareness of the capabilities and contributions of persons with disabilities' and 'foster respect for the rights and dignity of persons with disabilities'. This provision is the first of its kind to be included in an international human rights instrument. It is an example of the shift towards recognition of collective rights for minority groups. It signals that changing the way societies think and talk about disability is instrumental to realising its goals (Bariffi in Bantekas et al. 2018). So much will seem self-evident to disability scholars and activists, but what is not selfevident is the extent to which law - and in particular international human rights law - can drive these changes in societal perceptions and understanding of disability.

\section{Key elements of the UN Convention on the Rights of Persons with Disabilities}

The purpose of the CRPD is 'to promote, protect and ensure the full and equal enjoyment of all human rights and fundamental freedoms by all persons with disabilities, and to promote respect for their inherent dignity' (Article 1). It consists of 50 separate articles. Articles 5 to 30 set out the substantive rights protected by the Convention, while the remaining provisions establish mechanisms for implementation and monitoring.

Officially speaking, the Convention does not establish any new rights, but rather 'clarifies the obligations and legal duties of States to respect and ensure the equal enjoyment of all human rights by all persons with disabilities' (e.g. the UN Office of the High Commissioner for Human Rights and the Inter-Parliamentary Union 2007: 5). Many of the articles have 
titles that draw on those used by the UDHR, the ICCPR and the ICESCR, including the right to equality and non-discrimination (Article 5), equal recognition before the law (Article 12), the right to life (Article 10), liberty and security of the person (Article 14), freedom from torture, or cruel, inhuman and degrading treatment (Article 15), liberty of movement and nationality (Article 18), freedom of expression and opinion (Article 21), respect for privacy (Article 22), respect for home and the family (Article 23), the right to education (Article 24) and health (Article 25), work and employment (Article 27), participation in political and public life (Article 29) and participation in cultural life, recreation, leisure and sport (Article 30). Most rights include provisions to the effect that states parties must take effective or all necessary measures to ensure their enjoyment 'on an equal basis with others'. Waddington (2011: 436) describes the themes of equality and non-discrimination as running 'through the Convention like a red thread'. The benchmark against which successful implementation of the CRPD will be measured is the extent to which disabled people really do enjoy equal rights in comparison with others in their society.

Many substantive rights spell out in some detail the necessary steps to make equal enjoyment of previously recognised rights a reality. For example, the right to education is contained in several earlier human rights instruments (Article 26 of the UDHR, Article 13 of the ICESCR, Article 23 of the CRC and Article 2 of the ECHR). Article 24 of the CRPD spells out in considerable detail the measures that would be required to realise this for disabled children, from rights to 'reasonable accommodation' and support, to facilitating the learning of Braille, other forms of augmentative and alternative communication, to sign language, promoting the 'linguistic identify of the deaf community', and provisions concerning the training of teachers. The right to respect for home and the family, a civil and political rights stalwart (Article 12 of the UDHR, Article 17 of the ICCPR, Article 8 of the ECHR and Article 16 of the CRC), uniquely specifies in Article 23 of the CRPD that 'Persons with disabilities, including children, [shall] retain their fertility on an equal basis with others' and that 'States Parties shall render appropriate assistance to persons with disabilities in the performance of their child-rearing responsibilities'. For the first time in international human rights law, a right to 'reasonable accommodation' was explicitly spelled out, in the equality and non-discrimination provision of Article 5 of the CRPD, and defined in Article 2.

Despite the 'official fiction' that the CRPD creates no new rights, it does contain articles bearing entirely novel titles, and introduces many innovative measures and mechanisms (Kayess and French 2008: 32). For example, articles concerning accessibility (Article 9), living independently and being included in the community (Article 19), personal mobility (Article 20), habilitation and rehabilitation (Article 26), speak to specific concerns for disabled people. Whether these are 'new rights', or simply rights that are so securely (and thereby invisibly) enjoyed by most non-disabled people as not to attract specific protection in human rights treaties, is a matter for debate. Other 'new' rights emerged as more detailed specifications of previously recognised rights. For example, Article 13 on the right to access to justice emerged from the negotiations of Article 12, on the right to equal recognition before the law. The sparse text of Article 17 - on protecting the physical and mental integrity of the person - was already recognised in human rights jurisprudence, but emerged as a stand-alone provision in the CRPD.

\section{Implementation and monitoring of the Convention}

The CRPD introduces an innovative framework for implementation and monitoring of the

Convention. States parties must designate a 'focal point' within government to oversee 
implementation of the Convention (Article 33). Article 4 obliges states to adopt all appropriate legislative, administrative and other measures to implement the CRPD, and to modify or abolish existing laws, regulations, customs and practices that constitute discrimination against persons with disabilities. States must also designate or establish an 'independent mechanism' to 'to promote, protect and monitor implementation of the present Convention' (Article 33). This role is often undertaken by national human rights institutions (de Beco 2011).

The CRPD requires states to 'collect appropriate information, including statistical and research data, to enable them to formulate and implement policies to give effect to the present Convention' (Article 31). Statistical data is a 'potent tool' for undertaking comparative analyses of (un)equal treatment under discrimination law (Fredman 2011: 183).

Article 34 of the CRPD established the Committee on the Rights of Persons with Disabilities (CRPD Committee) to oversee and monitor the Convention. Members are elected by states parties, who must consider, inter alia, equitable geographical distribution, representation of 'different forms of civilization', balanced gender representation and 'participation of experts with disabilities'. Of the 18 independent experts elected in 2016 only one was not a disabled person (Löve et al. 2017). The CRPD Committee (2017) expressed concern that only one woman was elected.

States that have ratified the Convention must submit reports to the Committee at least every four years (Article 35). The Committee considers reports - possibly requesting further information - and makes observations and recommendations to individual states on the implementation of the Convention (Article 36). Although not specifically provided for in the Convention, civil society organisations frequently submit 'shadow reports' on the implementation of the Convention in their country, which inform the work of the Committee. Where states have also ratified the Optional Protocol to the CRPD (UN 2006), the Committee can consider individual complaints about human rights violations by states.

\section{Legal status and influence}

For states that have signed and ratified the CRPD, its status is binding in international law not 'soft law' as some political figures have mistakenly suggested (Joint Committee on Human Rights 2012). In the event that governments do not promote, protect and ensure the rights contained in the CRPD for disabled people, they are in breach of their international legal obligations. However, one of the key difficulties for international human rights law is the question of who, if anyone, will enforce a treaty or take action if violations occur. This is precisely why provisions for the implementation and monitoring of human rights Conventions are so vital.

The extent to which individuals can take legal action to enforce, or vindicate, their rights under the CRPD differs between states. In 'monist' states, international Conventions become part of domestic law once it is ratified, meaning that domestic courts can consider the provisions of the CRPD and may even strike down national legislation if it conflicts with a treaty obligation. In contrast, in 'dualist' legal systems, like that of the UK, a ratified treaty does not become an enforceable part of domestic law unless parliament specifically passes legislation to this effect (as, for example, it did with the ECHR under the Human Rights Act 1998). The status of the CRPD in the domestic courts of dualist states is persuasive where domestic law is ambiguous or unsettled - it is not binding in law. Yet a recent comparative study of 13 jurisdictions found that the domestic courts of both monist and dualist states are increasingly considering and interpreting the CRPD in order to fill gaps in domestic law, and to update it, even if not always quite in line with the intentions of its drafters (Lawson and Waddington 2018). 


\section{Key themes from the CRPD}

\section{'Nothing about us without us'}

It has become a truism that the CRPD, more than any other human rights treaty that came before it, embodies the spirit of the disability rights slogan 'nothing about us without us'. Klug (2000: 101) has described the UDHR as an 'élitist enterprise' that was not necessarily drafted by victims of repressive regimes themselves. Yet disabled people played a central role in the development of the CRPD. Kanter states that 'never before in the history of the UN were the subjects of a treaty invited to play such a prominent role in the drafting process' (2015: 8); she suggests that this has become a model for future human rights treaties.

The Ad Hoc Committee that negotiated the Convention eventually included over 400 representatives of civil society organisations from over 40 countries (Kanter 2006-2007; McKay 2006-2007). Many disability organisations worked together as the International Disability Caucus (IDC) in order to develop and adopt a position of 'unity' among the diverse organisations and groups represented (Reina 2008). A working group was established in 2003 to develop a draft Convention text for future negotiations. Following successful lobbying by disability organisations, it included prominent disability scholars and activists such as Tina Minkowitz, Gerard Quinn and Theresia Degener.

Lord recollects that during the first Ad Hoc Committee meeting in 2002:

the gallery space of the chosen conference room was inaccessible for people using wheelchairs. A move to a larger conference room (now the designated conference room for the remainder of the process) with equally inaccessible space for observers, forced disability activists to find space among delegates on the actual floor of the committee itself. This conferred a major advantage on participant NGOs, however, as they found themselves dispersed alongside delegates and IGO representatives.

(2004: 96)

The official records of the treaty negotiations (UN Enable) and accounts of participants (Kanter 2015; McKay 2006-2007; Dhanda 2006-2007; Minkowitz 2006; Reina 2008) reveal the very significant role played by civil society representatives in the development of the text of the CRPD. It has been suggested that as much as 80 per cent of the final text of the Convention came from the IDC (Kanter 2015, citing the Landmine Survivors Network).

The CRPD is a landmark achievement for inclusive lawmaking - both for disability advocates and the human rights community. It stands in stark contrast to the minimal inclusion of disabled people in the development of many human rights instruments that purport to serve them - from the MI Principles in the 1990s, to the recent outcry over the absence of 'meaningful consultation' with disability organisations by the Council of Europe's Committee on Bioethics in developing a binding protocol on involuntary treatment and placement of 'persons with mental disorders' (European Disability Forum 2018; CRPD Committee 2018). The CRPD has irrevocably shifted the benchmarks of legitimacy for the development of laws affecting disabled people. It has enshrined this principle into the treaty itself: Article 4(3) of the CRPD requires states parties to 'closely consult with and actively involve persons with disabilities, including children with disabilities, through their representative organizations'. The CRPD Committee (2018) has recently adopted a General Comment on the participation of persons with disabilities in the implementation and monitoring of the Convention, elaborating a definition of 'representative organisations' that privileges user-led organisations and an approach to disability advocacy founded on the CRPD. 
The remarkable achievement of the CRPD also casts an uncomfortable spotlight on difficult questions of representation in disability politics and advocacy. Reina (2008) describes how a position of unity for negotiations sometimes involved learning to live with unsolved problems and ambiguity - 'an inevitable consequence of being simultaneously different and unified'. Lord (2004) notes that many of the most influential members of the IDC did not satisfy the ultimate 'legitimacy test' of being grassroots membership organisations, and that all members of the core group of disabled person's organisations - the International Disability Alliance - were from the global north. Some groups of people directly affected by the Convention - most notably people with dementia - appear to have had little representation in the negotiations. And some commentators have questioned whether the strong position advocated for by the IDC on legal capacity and mental health detention reflects the views of most mental health service users (ibid.; Plumb in Spandler et al. 2015). There is, certainly, a danger that asking such difficult questions risks strengthening and legitimating existing practices that the Convention seeks to address, but it is also dangerous to leave unaddressed matters of 'representational over-reach' and questions about hierarchies of class, education, socially valued identity and access (Jones and Kelly in Spandler et al. 2015: 54).

\section{A human rights model of disability?}

A pivotal question for disability advocates was whether it would adopt a medical model, a social model or some other approach to disability. The CRPD negotiations considered wideranging 'definitions' of disability, with many states proposing medical model approaches that were resisted by disabled persons' organisations. Ultimately, the drafters of the Convention could not agree upon a 'definition' of disability, concerned that it might unwittingly (or deliberately) exclude some groups (Schulze 2010; Kakoullis and Ikehara in Bantekas et al. 2018). Instead, Article 1 of the CRPD contains an open-ended description, rather than a definition, of the treaty's target population:

Persons with disabilities include those who have long-term physical, mental, intellectual or sensory impairments which in interaction with various barriers may hinder their full and effective participation in society on an equal basis with others.

This description clearly foregrounds a 'social understanding of disability' (Traustadóttir 2009: 16), but the extent to which it reflects any particular model of disability is a matter for debate. Kayess and French (2008: 7) write that a 'populist' conceptualisation of the social model of disability was a primary influence on the development of the CRPD, with a tendency towards a 'radical social constructionist view of disability, rather than from its contemporary expression as a critical theory of disability'. Stein (2007) argues that the CRPD as a whole combines components of the social model of disability, with the human right to development and Nussbaum's version of the capabilities approach, filtered through a disability rights perspective. Degener (2017), the outgoing chair of the CRPD Committee, suggests that the Convention offers an alternative to both the medical model and the social model of disability - a 'human rights model' - but notes that most states parties to the Convention still adhere to a traditional medical model understanding of disability.

The CRPD's broad description of the target population is already reshaping states parties' approach to disability (Kakoullis and Ikehara in Bantekas et al. 2018; Lawson and Waddington 2018). For example, in 2013 the Court of Justice of the European Union adopted the CRPD's approach to disability, reversing an earlier medical model definition relied upon by the EU 
(HK Danmark v. Dansk almennyttigt Boligselskab, 2013). The potentially far-reaching consequences of this approach are exemplified by its finding in Karsten Kaltoft v. the Municipality of Billund (2014) that morbid obesity may fall within this definition of disability, and thereby qualify for protection against discrimination under EU law. Yet not all those who might be considered to fall within target population of the Convention will necessarily identify as 'disabled'. For example, several prominent users and survivors of psychiatry have contended that the social model of disability is not an adequate explanatory framework for their experiences (Spandler et al. 2015).

\section{From vulnerable to empowered?}

Article 3 of the CRPD establishes 'general principles' for the Convention. First among these is 'Respect for inherent dignity, individual autonomy including the freedom to make one's own choices, and independence of persons'. Other principles reference equality, non-discrimination, respect for diversity, participation and inclusion, accessibility and respect for the 'evolving capacities of children with disabilities', but 'protection' does not feature on this list. The language of 'vulnerability' does not feature in the Convention, and was actively resisted by DPOs during the drafting of Article 16 of the CRPD, concerned with exploitation and abuse (Schulze 2010; Keeling in Bantekas et al. 2018). This contrasts with characterisations of disabled people as inherently or especially vulnerable in feminist literature (e.g. Mackenzie et al. 2014; Fineman and Grear 2013) and in wider society.

Ideological conflicts between a view of disabled people as vulnerable and requiring protection - including through limits on rights to 'freedom to make one's own choices' - and a view of such protective interventions as themselves part of the problem that the CRPD should address, recurred throughout the negotiations of the Convention. There were heated debates on whether the CRPD should prohibit all forms of mental health detention, treatment without consent and mechanisms restricting legal capacity and permitting 'substitute decisions' by guardians or others. During the negotiations on the drafting of Article 15, the IDC maintained that forced treatment and institutionalisation were forms of 'torture' that the CRPD should explicitly prohibit, an approach that was resisted by states parties (Fennell in Bantekas et al. 2018). It was certainly the intention of many disability advocates that the Convention should prohibit all forms of mental health detention and forced treatment, and all forms of guardianship or disability-related restrictions on legal capacity - including those premised on 'mental incapacity' (Minkowitz 2006; Dhanda 2006-2007).

The CRPD Committee $(2014,2015)$ interprets the Convention as prohibiting all forms of mental health detention, compulsory treatment, restrictions on legal capacity and substitute decision-making. The status of the Committee's interpretation of the Convention is authoritative, but it is not legally binding upon states; few would have ratified the Convention if they shared this interpretation. There has been a backlash against the Committee's position, from clinicians in particular (e.g. Freeman et al. 2015; Appelbaum 2016). Some prominent users and survivors of psychiatry have also expressed concern about this absolutist position (Plumb in Spandler et al. 2015; Jones and Shattell 2014; Rose in Bhugra et al. 2017: 794). The question of whether the Convention does in fact prohibit all forms of mental health detention, treatment without consent and restrictions on legal capacity is a matter of ongoing discussion and debate (Bantekas et al. 2018).

Radical interpretations of the Convention, which divorce legal agency and the exercise of rights from the concepts of 'mental capacity' and 'mental disorder', have been described as 'the most revolutionary of the new norms articulated in the CRPD (Minkowitz 2006: 408). 
It is in this arena that the intellectual battles for a new paradigm are at their most contested and complex; there is insufficient space in this chapter to do justice to the wide-ranging issues and considerations. However, it is certainly an area that is in much need of input from disability and Mad Studies scholarship, user and survivor researchers, engagement with grassroots disability and user and survivor organisations, and - perhaps most importantly - those who are affected but who are not engaged in disability activism. We must take these important discussions and debates outside the elite arenas of legal, ethical and clinical scholarship.

\section{Paradoxes of rights}

To summarise, then, human rights as they developed in the second half of the twentieth century only very gradually recognised the specific situation of disabled people, despite gross and widespread human rights violations perpetrated against the world's 'fastest growing minority' (Kanter 2015: 21). The CRPD is a landmark achievement for disability advocacy and human rights. It represents an inflection point in our understanding of what it means to be a bearer of rights, and the role of states and the global community in promoting, protecting and ensuring those rights. The CRPD is widely described as embodying a paradigm shift in approaches to disability and to human rights, but this paradigm shift is far from achieved. Intellectual battles continue to rage, and as Fennell (in Bantekas et al. 2018) has noted, it operates in tandem with an 'old' paradigm of disability and human rights at the level of the Council of Europe, several UN bodies and national law. No country yet complies with all the provisions of the CRPD, and many countries face a conflict of laws in deciding whether to apply the human rights norms of the CRPD or other legal instruments, such as the ECHR, which continue to be based on conflicting norms and obligations.

To suggest that this signals failure is to misunderstand human rights law, and indeed the nature of 'revolutions' in paradigms of thought. No human rights instrument was ever born with fully fledged jurisprudence, and human rights norms continue to develop and evolve throughout the lifetime of a treaty. There simply is no human rights treaty that has been fully implemented, or any country that fully complies with all human rights law. The critical question for the CRPD is what compliance could actually look like for some of its more radical norms and interpretations, and in this respect there is ample scope for further study and inclusive discussion and debate. That many of these new norms are resisted and contested by governments, law reform and professional bodies at the very least signals that they are finally being required to justify positions that have previously been regarded as unassailable and unquestionable.

The CRPD, like any other human rights treaty, has the potential to be differentially interpreted and (mis)applied. As Quinn states:

the text alone does not guarantee that its values will be transposed into the worldview of policy and law-makers and that there will always be textual toeholds to be found in the Convention - in any convention - that can potentially allow States to temporise the profound reforms that its underlying philosophy demands. This is no more than what the Legal Realists have taught us several decades ago.

(2009: 2017)

Mladenov (2012) anticipated ongoing struggles over the CRPD's meaning in the terrains of national and international lawmaking, policy planning, implementation and monitoring, and 
contends that politically engaged communities are a crucial condition for the realisation of the Convention's potential.

The wider field of critical human rights scholarship has observed that 'rights'-based strategies can differentially empower and reinforce existing inequalities (Brown 2002; Rose 1985). Others express a broader scepticism about the power of law to achieve social transformation (Rosenberg 2008). Prominent disability activists and scholars have questioned the efficacy of 'the drift towards a rights-based approach that now dominates disability politics' (Oliver and Barnes 2006). These critical insights temper our expectations of the CRPD, and keep alive the importance of disability politics and activism alongside legal strategies. Yet without legal strategies, the law would not simply evaporate, but instead would continue to operate on and reinforce the norms and understandings that permit and legitimate oppression, isolation, exclusion and inequality. The CRPD is fundamental to unpicking them.

\section{Note}

1 Similar text can be found in the Preamble to the European Convention on Human Rights (Council of Europe, 1950).

\section{References}

Appelbaum, P. S. (2016) 'Protecting the Rights of Persons with Disabilities: An International Convention and Its Problems', Law \& Psychiatry 67(4): 366.

Bantekas, I., Stein, M. and Anastasiou, D. (eds) (2018) Commentary on UN Convention on the Rights of Persons with Disabilities, Oxford: Oxford University Press.

Beitz, C. R. (2009) The Idea of Human Rights, Oxford: Oxford University Press.

Bhugra, D. et al. (2017) 'The WPA Lancet Psychiatry Commission on the Future of Psychiatry', Lancet Psychiatry 4(10): 775.

Brown, W. (2002) 'Suffering the Paradoxes of Rights', in W. Brown and J. Halley (eds) Left Legalism/Left Critique, Durham, NC: Duke University Press.

Chandler, D. (2001) 'Universal Ethics and Elite Politics: The Limits of Normative Human Rights Theory', International Journal of Human Rights 5(4): 72.

Clifford Simplican, S. (2015) The Capacity Contract: Intellectual Disability and the Question of Citizenship, Minneapolis: University of Minnesota Press.

Daes, E.-I. (1986) Principles, Guidelines and Guarantees for the Protection of Persons Detained on Grounds of Mental IllHealth or Suffering from Mental Disorder, report of the Special Rapporteur of the Sub-Commission on Prevention of Discrimination and Protection of Minorities, UN Doc E/CN4/Sub2/1983/17, New York: United Nations.

Dhanda, A. (2006-2007) 'Legal Capacity in the Disability Rights Convention: Stranglehold of the past or Lodestar for the Future', Syracuse Journal of International Law and Commerce 34: 429-462. Available at http://dx.doi.org/10.1163/ej.9789004154230.i-382.38.

Darrow, M. 1996. 'International Human Rights Law and Disability: Time for an International Convention on the Human Rights of People with Disabilities?' Australian Journal of Human Rights 3(1): 69.

De Beco, G. (2011) 'Article 33(2) of the UN Convention on the Rights of Persons with Disabilities: Another role for national human rights institutions?', Netherlands Quarterly of Human Rights 29(1): 84.

Degener, T. (2017) 'A New Human Rights Model of Disability', in V. Della Fina, R. Cera and G. Palmisano (eds) The United Nations Convention on the Rights of Persons with Disabilities: A Commentary, New York: Springer International Publishing.

Despouy, L. (1991) Human Rights and Disabled Persons, report by the Special Rapporteur of the United Nations Sub-Commission on Prevention of Discrimination and Protection of Minorities, UN Doc E/ CN4/Sub2/1991/31, New York: United Nations.

Disabled Peoples' International, Inclusion International, Rehabilitation International, World Blind Union, World Federation of the Deaf and national non-governmental organisations (2000) 'Beijing Declaration on the Rights of People with Disabilities in the New Century', adopted at the World NGO Summit 


\section{Disability and human rights}

on Disability, Beijing, 12 March. Available at www.dinf.ne.jp/doc/english/asia/conf/z00021/ z0002101.html.

Donnelly, J. (1984) 'Cultural Relativism and Universal Human Rights', Human Rights Quarterly 6(4): 400.

Douzinas, C. (2007) Human Rights and Empire: The Political Philosophy of Cosmopolitanism, Abingdon: Routledge-Cavendish.

European Commission of Human Rights (1956) 'Preparatory Work on Article 3 of the European Convention on Human Rights'. Available at www.echr.coe.int/LibraryDocs/Travaux/ECHRTravaux-ART3-DH(56) 5-EN1674940.pdf.

European Disability Forum (2018) 'Disability Organisations Urge Council of Europe to Withdraw Additional Protocol of Oviedo Convention', Brussels:European Disability Forum. Available at www.edf-feph.org/ newsroom/news/disability-organisations-urge-council-europe-withdraw-addition-protocol-oviedo.

Feldman, D. (1999) 'Human Dignity as a Legal Value, Part 1', Public Law (winter): 682.

Fineman, M. A. and Grear, A. (eds) (2013) Vulnerability: Reflections on a New Ethical Foundation for Law and Politics, Farnham: Ashgate.

Fredman, S. (2011) Discrimination Law, 2nd edn, Oxford: Clarendon Press.

Freeman, M. C. et al. (2015) 'Reversing Hard Won Victories in the Name of Human Rights: A Critique of the General Comment on Article 12 of the UN Convention on the Rights of Persons with Disabilities', Lancet Psychiatry 2(9): 844.

Hammarberg, T. (2011) 'Disability Rights: From Charity to Equality', European Human Rights Law Review 6: 638.

Holbrook, J. and Allan, J. (2017) Global Governance: The Challenge to the UK's Liberal Democracy, London: Policy Exchange.

Joint Committee on Human Rights (2012) Implementation of the Right of Disabled People to Independent Living, HL Paper 257, HC 1074, London: Joint Committee on Human Rights.

Jones, N. and Shattell, M. (2014) 'Beyond Easy Answers: Facing the Entanglements of Violence and Psychosis', Issues in Mental Health Nursing 35(10): 809.

Kanter, A. (2015) The Development of Disability Rights under International Law: From Charity to Human Rights, Abingdon and New York: Routledge.

Kanter, A. S. (2006-2007) 'The Promise and Challenge of the United Nations Convention on the Rights of Persons with Disabilities', Syracuse Journal of International Law and Commerce 34: 287.

Kayess, R. and French, P. (2008) 'Out of Darkness into Light? Introducing the Convention on the Rights of Persons with Disabilities', Human Rights Law Review 8(1): 1.

Kittay, E. F. and Carlson, L. (eds) (2010) Cognitive Disability and Its Challenge to Moral Philosophy, Chichester: John Wiley \& Sons.

Klug, F. (2000) Values for a Godless Age: The Story of the United Kingdom's New Bill of Rights, London: Penguin.

Kuhn, T. ([1962] 2012) The Structure of Scientific Revolutions, 50th anniversary edn, Chicago, IL: University of Chicago Press.

Lawson, A. (2006-2007) 'The United Nations Convention on the Rights of Persons with Disabilities: New Era or False Dawn?', Syracuse Journal of International Law and Commerce 34: 563.

Lawson, A. and Waddington, L. (eds) (2018) Domestic Interpretation of the UN Convention on the Rights of Persons with Disabilities: A Comparative Analysis, Oxford: Oxford University Press.

Lord, J. (2004) 'Mirror, Mirror on the Wall: Voice Accountability and NGOs in Human Rights Standard Setting', Seton Hall Journal of Diplomacy and International Relations 93.

Löve, L. et al. (2017) 'The Inclusion of the Lived Experience of Disability in Policymaking', Laws 6: 33.

Mckay, D. (2006-2007) 'The United Nations Convention on the Rights of Persons with Disabilities', Syracuse Journal of International Law and Commerce 34: 323.

Mackenzie, C., Rogers, W. and Dodds, S. (eds) (2014) Vulnerability: New Essays in Ethics and Feminist Philosophy, Oxford: Oxford University Press.

Marx, K. (1844) On the Jewish Question.

Minkowitz, T. (2006) 'The United Nations Convention on the Rights of Persons with Disabilities and the Right to be Free from Nonconsensual Psychiatric Interventions', Syracuse J. Int'l L. \& Com. 34: 405.

Mladenov, T. (2012) 'The UN Convention on the Rights of Persons with Disabilities and its Interpretation', ALTER: European Journal of Disability Research/Revue Européenne de Recherche sur le Handicap 7(1): 69.

Moeckli, D., Shah, S. and Sivahumaran, S. (eds) (2014) International Human Rights Law, 2nd edn, Oxford: Oxford University Press.

Naffine, N. (2003) 'Who are Law's Persons? From Cheshire Cats to Responsible Subjects', Modern Law Review 66(3): 346. 


\section{Disability and human rights}

Neal, M. (2012) 'Not Gods but Animals : Human Dignity and Vulnerable Subjecthood', Liverpool Law Review 23 (3): 177.

Nickel, J. (2017) 'Human Rights', Stanford Encyclopedia of Philosophy, ed. Edward N. Zalta, Stanford, CA: The Metaphysics Research Lab, Center for the Study of Language and Information, Stanford University. Availa ble athttps://plato.stanford.edu/.

Nussbaum, M. (2009) 'The Capabilities of People with Cognitive Disabilities', Metaphilosophy 40(3): 331.

Oliver, M. and Barnes, C. (2006) 'Disability Politics and the Disability Movement in Britain: Where Did It All Go Wrong?', Leeds: Leeds University Disability Studies Archive. Available at https://disabili ty-studies.leeds.ac.uk/wp-content/uploads/sites/40/library/Barnes-Coalition-disability-politics-paper. pdf.

Quinn, G. (2009) 'The United Nations Convention on the Rights of Persons with Disabilities: Toward a New International Politics of Disability', Texas Journal of Civil Liberties and Civil Rights 15(1): 33.

Quinn, G. and Arstein-Kerslake, A. (2012) 'Restoring the "Human" in "Human Rights": Personhood and Doctrinal Innovation in the UN Disability Convention', in C. Gearty and C. Douzinas (eds) Cambridge Companion to Human Rights Law, Cambridge: Cambridge University Press.

Quinn, G. and Degener, T. (2002) The Current Use and Future Potential of United Nations Human Rights Instruments in the Context of Disability, Geneva: United Nations. Available at https://www.ohchr.org/ Documents/Publications/HRDisabilityen.pdf.

Reina, M. V. (2008) 'How the International Disability Caucus Worked during Negotiations for a UN Human Rights Convention on Disability', New York: Global Action on Aging. Available at http:// globalag.igc.org/agingwatch/events/CSD/2008/maria.htm.

Rose, N. (1985) 'Unreasonable Rights: Mental Illness and the Limits of the Law', Journal of Law and Society 12(2): 199.

Rosenberg, G. N. (2008) The Hollow Hope: Can Courts Bring About Social Change?2nd edn, Chicago: University of Chicago Press.

Rosenthal, E. and Rubenstein, L. S. (1993) 'International Human Rights Advocacy under the 'Principles for the Protection of Persons with Mental Illness', International Journal of Law and Psychiatry 16(3): 257.

Russell, M. (2002) 'What Disability Civil Rights Cannot Do: Employment and Political Economy', Disability \& Society 17(2): 117.

Schulze, M. (2010) Understanding the UN Convention on the Rights of Persons with Disabilities, Lyon: Handicap International. Available at https://iddcconsortium.net/sites/default/files/resources-tools/files/hi_crp d_manual_sept2009_final.pdf.

Series, L. (2015) 'Relationships, Autonomy and Legal Capacity: Mental Capacity and Support Paradigms', International Journal of Law and Psychiatry 40: 80.

Spandler, H., Anderson, J. and Sapey, B. (2015) Madness, Distress and the Politics of Disablement, Policy Press.

Steel, H. (1991) 'Report of the Working Group on the Principles for the Protection of Persons with Mental Illness and for the Improvement of Mental Health Care', UN Doc/CN4/1991/39, New York: United Nations.

Stein, M. A. (2007) 'Disability Human Rights', California Law Review 95(1): 75.

Stein, M. A. and Lord, J. E. (2009) 'Monitoring the Convention on the Rights of Persons with Disabilities: Innovations, Lost Opportunities, and Future Potential', Human Rights Quarterly 32: 659.

Traustadóttir, R. (2009) 'Disability Studies, the Social Model and Legal Developments', in O. M. Arnardóttir and G. Quinn (eds) The UN Convention on the Rights of Persons with Disabilities European and Scandinavian Perspectives, Leiden: Martinus Nijhoff Publishers.

Turner, B. S.. (2006) Vulnerability and Human Rights, Philadelphia: Pennsylvania State University Press.

United Nations (UN) Enable (n.d.) 'Ad Hoc Committee on a Comprehensive and Integral International Convention on the Protection and Promotion of the Rights and Dignity of Persons with Disabilities'. Available at www.un.org/esa/socdev/enable/rights/adhoccom.htm.

United Nations Office of the High Commissioner for Human Rights and the Inter-Parliamentary Union (2007) 'From Exclusion to Equality: Realizing the Rights of Persons with Disabilities', Handbook for Parliamentarians on the Convention on the Rights of Persons with Disabilities and its Optional Protocol, Geneva: United Nations.

Vorhaus, J. (2005) 'Citizenship, Competence and Profound Disability', Journal of Philosophy of Education 39 (3): 461.

Waddington, L. (2011) 'The European Union and the United Nations Convention on the Rights of Persons with Disabilities: A Story of Exclusive and Shared Competences', Maastricht Journal 18(4): 431. 


\section{International human rights instruments - United Nations declarations and resolutions (non-binding)}

'Universal Declaration of Human Rights', adopted 10 December 1948, United Nations General Assembly Resolution 217 A(III) (UDHR).

'Draft International Covenant on Human Rights and measures of implementation; future work of the Commission on Human Rights' adopted on 4 December 1950, United Nations General Assembly Resolution 420.

'Declaration on the Rights of Mentally Retarded Persons', adopted 20 December 1971, United Nations General Assembly Resolution 2856 (XXVI).

'UN Declaration on the Rights of Disabled Persons', adopted 9 December 1975, United Nations General Assembly Resolution 3447 (XXX).

'The Protection of Persons with Mental Illness and the Improvement of Mental Health Care', adopted 17 December 1991, United Nations General Assembly Resolution 46/119 ('MI Principles').

\section{Binding international Conventions - Council of Europe}

'Convention for the Protection of Human Rights and Fundamental Freedoms', adopted 4 November 1950, entered into force 3 September 1953, European Treaty Series No. 5 (ECHR).

\section{Binding international Conventions - Organization of American States}

'Inter-American Convention on the Elimination of all forms of Discrimination against Persons with Disabilities', opened for signature on 7 June 1999, AG/RES. 1608 (XXIX-O/99).

\section{United Nations Conventions}

'International Covenant on Civil and Political Rights', opened for signatures 6 December 1966, 999 United Nations Treaty Series 14668 (ICCPR)

'International Covenant on Economic, Social and Cultural Rights', opened for signatures 16 December 1966, 999 United Nations Treaty Series 2 (ICESCR)

'Convention on the Elimination of All Forms of Discrimination against Women', opened for signatures 18 December 1979, 1249 United Nations Treaty Series 13 (CEDAW)

'Convention on the Rights of the Child', opened for signatures 20 November 1989, 2171 United Nations Treaty Series 227 (CRC).

'International Convention on the Protection of the Rights of All Migrant Workers and Members of Their Families', opened for signatures 18 December 1990, 2220 United Nations Treaty Series 3.

'Optional Protocol to the Convention against Torture and other Cruel, Inhuman or Degrading Treatment or Punishment', opened for signatures 18 December 2002, 2375 United Nations Treaty Series 237 (OPCAT)

'Convention on the Rights of Persons with Disabilities', opened for signatures 13 December 2006, 2515 United Nations Treaty Series 3 (CRPD).

'Optional Protocol to the Convention on the Rights of Persons with Disabilities', opened for signatures 13 December 2006, 2515 UNTS 3 (OPCRPD).

\section{Committee on the Rights of Persons with Disabilities: general comments, statements and guidelines}

General comment No 1 (2014) Article 12: Equal recognition before the law. Adopted 19 May 2014. UN Doc CRPD/C/GC/1.

Guidelines on Article 14 of the Convention on the Rights of Persons with Disabilities. Adopted during the Committee's 14th session, held in September 2015.

Achieving gender balance and equitable geographical representation in the elections of members of the Committee. Statement of the Committee on the Rights of Persons with Disabilities. Adopted during the Committee's 17th session, held 20 March-12 April 2017. 


\section{Disability and human rights}

General comment No. 7 (2018) on the participation of persons with disabilities, including children with disabilities, through their representative organisations, in the implementation and monitoring of the Convention. Adopted on 9 November 2018. UN Doc CRPD/C/GC/7.

Statement by the Committee on the Rights of Persons with Disabilities calling States parties to oppose the draft Additional Protocol to the Oviedo Convention. Adopted during the Committee's 20th session, held 27 August-21 September 2018 in Geneva, Switzerland.

\section{Cases}

HK Danmark v. Dansk almennyttigt Boligselskab EUECJ C-335/11 (11 April 2013)

Karsten Kaltoft v. Municipality of Billund EUECJ C-354/13 (18 December 2014) 